\title{
Potential impacts of climate change on soil properties
}

\author{
${ }^{1}$ Gelybó G., ${ }^{1}$ Tóth E., ${ }^{1,2}$ FArkas C., ${ }^{1}$ Horel Á., ${ }^{1}$ KásA I., ${ }^{1}$ BAKAcsi Z. \\ ${ }^{1}$ Department of Soil Science, Institute for Soil Sciences and Agricultural Chemistry, \\ Centre for Agricultural Research, Hungarian Academy of Science, Budapest \\ ${ }^{2}$ NIBIO, Norwegian Institute of Bioeconomy Research, Ås, Norway
}

\begin{abstract}
Climate change is expected to have a vigorous impact on soils and ecosystems due to elevated temperature and changes in precipitation (amount and frequency), thereby altering biogeochemical and hydrological cycles. Several phenomena associated with climate change and anthropogenic activity affect soils indirectly via ecosystem functioning (such as higher atmospheric $\mathrm{CO}_{2}$ concentration and $\mathrm{N}$ deposition). Continuous interactions between climate and soils determine the transformation and transport processes. Long-term gradual changes in abiotic environmental factors alter naturally occurring soil forming processes by modifying the soil water regime, mineral composition evolution, and the rate of organic matter formation and degradation. The resulting physical and chemical soil properties play a fundamental role in the productivity and environmental quality of cultivated land, so it is crucial to evaluate the potential outcomes of climate change and soil interactions. This paper attempts to review the underlying long-term processes influenced by different aspects of climate change. When considering major soil forming factors (climate, parent material, living organisms, topography), especially climate, we put special attention to soil physical properties (soil structure and texture, and consequential changes in soil hydrothermal regime), soil chemical properties (e.g. cation exchange capacity, soil organic matter content as influenced by changes in environmental conditions) and soil degradation as a result of longterm soil physicochemical transformations. The temperate region, specifically the Carpathian Basin as a heterogeneous territory consisting of different climatic and soil zones from continental to mountainous, is used as an example to present potential changes and to assess the effect of climate change on soils. The altered physicochemical and biological properties of soils require accentuated scientific attention, particularly with respect to significant feedback processes to climate and soil services such as food security.
\end{abstract}

Keywords: climate change, climate-soil interaction, soil degradation, water regime, climate modelling

Postal address: EsZTER TóTH, Department of Soil Science, Institute for Soil Sciences and Agricultural Chemistry, Centre for Agricultural Research, Hungarian Academy of Science, 1022 Budapest, Herman O. út 15.

E-mail: teszter@rissac.hu 


\section{Climate as a soil forming factor}

Soil forming factors determine and/or influence the formation of soil cover on the terrestrial land surface (PIVCHENKO, 2010). Soil scientists distinguish the effect of four major soil formation factors (DOKUCHAEV, 1899; JENNY, 1941): parent material, climate, living organisms and topography over time. The great variability of soil forming factors on Earth led to the formation of soil types and the unrepeatable mosaic of soil cover (BOCKHEIM et al., 2014). More than 100 years ago DOKUCHAEV (1899) and later JENNY (1941) described and formalized the functional relationship between soil cover and the main soil forming factors.

Soil forming factors and their specific roles in soil formation are well known (e.g. DOKUCHAEV, 1899; JENNY, 1941; YAALON, 1983; ANDERSON, 1988; BARD et al., 2002). Since the aim of the present review centred on the potential effects of climate on soil hydro-physical and chemical properties, the main focus was to investigate the effect of climate, out of the four main soil forming factors mentioned above.

Soil forming factors determine specific soil processes, and the most important climatic factors in pedogenic processes are temperature, precipitation and their variations (YAALON, 1983; ANDERSON, 1988; BARD et al., 2002). To evaluate the possible effects of climate change on soil properties and soil forming processes we need to pinpoint the main climate-driven factors that directly or indirectly affect soil development and soil properties. During soil formation different physical and chemical processes take place, which require various time scales to happen. When a soil reaches the state of "maturity", the soil processes become steady state or come to quasi-equilibrium with the environment; however, environmental changes, such as change in precipitation amount, can significantly modify the pathways of soil development, as found by studies on paleosols (BIRKELAND, 1999; MACK, 1991).

Another important aspect in soil forming processes is the timescale when the four soil forming factors occur. TARGULIAN \& KRASILNIKOV (2007) suggested that pedogenic processes mostly occur on three separate time scales. While rapid pedogenic processes happen in ten to hundred years (e.g. compaction, salinization), there are also medium $\left(10^{3}-10^{4}\right.$ years; e.g. lessivage; mollic, umbric humification) and slow rate $\left(10^{5}-10^{6}\right.$ years; e.g ferallitization) processes (TARGULIAN \& KRASILNIKOV, 2007). YAALOON (1983) used different time scales to characterize pedogenic processes as rapid $\left(<10^{3}\right.$ years), such as organic matter formation, and slow ( $>10^{3}$ years) processes, e.g. argillic or oxic horizon formation.

Climate, as one of the most important determining factors of soil formation, has direct and indirect effects on soil development (HOTCHKISS et al., 2000). Its direct effect can be expressed through the influence of climatic factors such as heat, radiation and precipitation on the soil environment (MOLNAR \& ENGLAND, 1990). The indirect impacts are mainly represented by the influence of climate on the biosphere in general, which also affects soil properties and formation. Hence, combinations of temperature and moisture conditions can determine the conversion processes of mineral compounds in the soil, such as the rate of weathering and the accumulation of soil forming products; the vegetation type; the rate of organic 
matter formation and degradation; the components and intensity of soil microflora and fauna functioning; and water erosion processes.

\section{Interaction between climate change and soils}

The climate may significantly influence the dominant vegetation types, their productivity, the chemical characteristics and decomposition of their litter deposits, and the development of soil reactions (BRINKMAN \& BRAMMER, 1990; SCHARPENSEEL et al., 1990). In general, soil structure can be influenced by changing climatic conditions in various directions, on different time scales, and with different intensities. Changes in climatic factors such as precipitation intensities or seasonal temperatures can greatly influence soil hydrophysical properties. These changes affect the soil water regime, which may ultimately impact the environmental and economic development of a given area (HOREL et al., 2014).

Solar radiation and precipitation are the main sources of energy and moisture, respectively, for both biological and soil processes (REY, 2015). Solar radiation is absorbed and reemitted by the Earth's surface, which gradually heats the atmosphere. Precipitation is absorbed by the soil, used by plants and subsequently returned to the atmosphere via the processes of evaporation and transpiration. Thus, a continuous latent and sensible heat flux is present between the soil and the atmosphere, influencing the hydrothermal regime of the soil.

Any changes in climatic factors can modify soil properties on the characteristic time scale of the driving processes. Soil energy and water balance components can respond rapidly to changes in atmospheric conditions. Changes in soil organic carbon content (SOC) are slower, but can still be detected on climatological time scales. Soil erosion gives a relatively fast response to climatic changes, especially to changes in precipitation intensity. Soil quality has implications in ecosystem services, also influencing food security (SINGH et al., 2011). Although these interactions are very important the present paper focuses mainly on long-term changes in soil hydro-physical and chemical properties in relation to climate change.

\subsection{Soil physical properties and climate change}

The hydrological characteristics of soils (e.g. water retention, hydraulic conductivity) are determined by the soil physical properties, the most important of which are the texture or mechanical composition of the soil; structure, such as shape and stability; porosity and bulk density; and pore-size distribution, all of which contribute to the water, air and heat management of the soil profile (HILLEL, 1973). The physical properties of the soil have a great influence on its chemical and biological processes, such as adsorption, water, heat and mass transport, biological activity, nutrient supply, etc., and through them on soil fertility (HILLEL, 1973; HOREL et al., 2015). However, it is difficult to differentiate between soils physical properties separately in relation to their sensitivity to climate change, because they are strongly interrelated. For example, MiLLs et al. (2014) found that soil moisture stress may significantly reduce soil function, consequently affecting plant 
productivity. Theoretically, four major scenarios can be forecasted based on changes in temperature and amount of precipitation, specifically 1) decreasing temperature with decreasing precipitation; 2) decreasing temperature with increasing precipitation; 3) increasing temperature with decreasing precipitation; and 4) increasing temperature with increasing precipitation. The expected impacts of the two most probable scenarios on certain pedogenic processes are demonstrated in Figure 1.

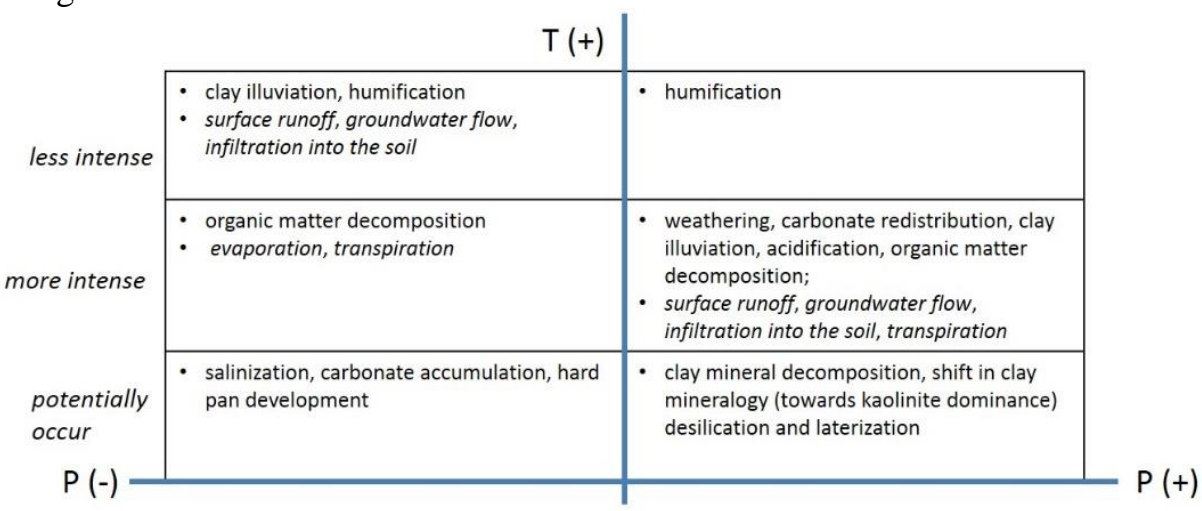

Figure 1

Effect of hypothetical climatic changes ( $\mathrm{T}$ and $\mathrm{P}$ represent temperature and precipitation, respectively) on specific soil processes and the main elements of the soil moisture regime; based on BRINKMAN \& BRAMMER (1990), SCHARPENSEEL et al. (1990) and VÁRALLYAY

(2010).

Figure 1 shows the expected impact of hypothetical climatic changes on specific soil processes, both under warm/wet and warm/dry scenarios, but cannot consider the high spatial and temporal variability of the elements of climate. Under changing conditions the direction and strength of specific soil processes may vary, becoming inhibited or enhanced. In a warming/drying environment, due to the less intensive infiltration into the soil, related mass transport processes, such as the downward movement of clay in the soil, will also become inhibited. Moreover, newly emerging processes could affect soil profile development at a given site; for instance increasing temperature could accelerate the decomposition of organic matter. The results obtained using climate models suggest that an increase in both average annual temperatures and seasonal mean temperatures can be expected in both summer and winter in the mid-latitudes, accompanied by a slight increase or no change in annual precipitation totals (IPCC AR4-5). This would result in a hot wet shift in environmental conditions e.g. in Eastern Central Europe, leading to minimum clay illuviation on longer time scales. On the other hand, precipitation changes are not in such a global agreement. Different geographical locations may face either an increase or decrease in annual precipitation (IPCC AR5). Hence, more attention should be paid to the warm wet and warm dry scenarios among the four cases above. 


\section{Soil texture}

Soil texture is a basic determinant of soil characteristics. It changes very slowly, in the soil formation time scale, hence is not prone to be affected on the time scale relevant to climate change studies. However, among other features, the soil texture determines the sensitivity of a soil to changes in climatic factors.

Regarding the cracking and shrinking phenomenon of clay soils, however, these soils appeared to be also sensitive to a changing climate if the number of wetting and drying cycles increases. Repeated wetting and drying in shrinkingswelling clay soils greatly facilitates the formation of cracks in the soil. Deep cracks result rapid, direct movement of water from the surface soil to permeable substrata or drainage installations through bypass flow. It can decrease the filtering function of the soil and increase the likelihood of nutrient losses and water pollution Rounsevell et al., 1999; IPCC Climate CHANGE, 2007). These processes already occur in clay soils, but water and material losses due to bypass flow could increase if longer, more frequent drought events occur, followed by more intensive precipitation events.

BORMANN et al. (2012) studied the soil texture-specific sensitivity of soil moisture regimes to climate change by applying a physically based Soil-VegetationAtmosphere-Transfer model (SVAT, using both A1B and B1 emission scenarios) to virtual soil columns representing various soil textures. The results demonstrated that soils with different texture had different reactions to changing climatic conditions, especially in the case of the A1B scenario. BORMANN et al. (2012) found that changes in the seasonal soil moisture regime were strongly determined by the regional changes in climate and by climate-induced changes in capillary moisture transport from the groundwater to the root zone. The authors found that soils with the highest water retention capacity (silt soils) reacted most sensitively to changes in climatic parameters, whereas clay soils showed the least sensitivity; however, sensitivity was also a function of groundwater depth or capillary rise, vegetation density, rooting depths and transpiration (BORMANN et al., 2012). The sensitivity pattern was found to depend on soil texture and to be affected by the model boundary conditions applied (e.g. groundwater level, vegetation), but generally the soil texture is the dominant influencing factor, determining how a soil reacts to regional climate change. ISTANBULLUOGLU \& BRAS (2006) also emphasized the importance of soil texture in controlling the magnitude and shape of climate-soil vegetation-landscape functions but did not analyse their sensitivity to climate change. According to IsTANBULLUOGLU \& BRAS (2006) soil texture greatly influences biomass production and the type of vegetation that can be grown in a given area, e.g. the authors found that grass cover may diminish as the soil texture becomes finer.

\section{Porosity and bulk density}

It has been noted that the influence of climate change on soil structure, type and spatial distribution, and on the stability of soil aggregates is a very complex process (VÁRALLYAY, 2010). 
Changes in the amount and temporal distribution of precipitation and increases in temperature directly affect the soil structure via the processes of slaking, dispersion, mechanical disturbance and compaction (REUBENS et al., 2007; BOCKHEIM, 1980). The most important direct impacts of climate on the soil structure are the destructive potential of raindrops, surface runoff and filtrating water, and extreme rain events (VÁRALLYAY, 2005, 2010). Based on observations in recent years, extreme weather events and hydrological situations are likely to increase in Central Europe in the near future (SZÁSZ et al., 1994; BARTHOLY et al., 2007). Therefore, increased drought and/or inland water can be expected in agricultural settings (FARKAS et al., 2009).

Indirect effects are caused by changes in the vegetation pattern and functioning, in land use practices (SINGH et al., 2011; POST, 1982) and in the biological functioning of the soil (due to the sensitivity of earthworms, termites and soil microorganisms to climate change), which also affect the soil structure (VÁRALlYAY, 2010). Bulk density, which is closely related to soil textural properties and organic matter content, is also climate dependent (CROCKER \& MAJOR, 1955; POST, 1982). The loss of soil organic matter due to an increased decomposition rate or soil erosion may increase bulk density, leading to soil compaction (SINGH et al., 2011; BIRKÁS et al., 2009) with all its consequences, such as decreasing porosity and compact layer formation inhibiting root growth. Root development, as well as microbial activity, may be altered by climate change via changes in soil water and temperature regimes and changes in soil hydro-physical properties such as alterations in bulk density or the development of preferential flow paths (HILLEL, 1973; RosENZWEIG \& HiLLEL, 1995).

\section{Structure: shape and stability}

Soil aggregate size and stability (which also characterise soil structure), together with porosity and pore size distribution are fundamental determinants of the moisture and aeration status of the soil. Any changes in porosity directly affect the soil water storage capacity (infiltration, water retention) and may change soil $\mathrm{CO}_{2}$ (aerobic conditions) and $\mathrm{CH}_{4}$ (anaerobic conditions) emissions (PORPORATO et al., 2004; SINGH et al., 2011; TóTH et al., 2018). Intensive rainfall, and directly the raindrops have important impact on aggregate destruction (SINGH et al., 2011; VÁRALLYAY, 2007). Increasing temperature, coupled with the lower available water, less biomass and soil organic matter content can lead to a decrease in aggregate size and stability (LAVEE et al., 1998).

\section{Soil hydrothermal regime}

The integrated effect of climatic and related hydrological-, vegetation- and land use changes on soil functioning are reflected by the field water balance and soil moisture regime (YAALON, 1983; VÁRALLYAY, 2007; FARKAS, 2009; SURDA et al., 2015). The soil moisture dynamics integrates and reflects seasonal changes in soil moisture reserves, the amount of plant-available water, leaching to deeper layers, and weathering, and is thus a useful descriptor of the soil forming environment. Soil water availability and water retention, which strongly determine 
ecosystem functioning are interdependent on the infiltration rate. According to SINGH et al. (2011), infiltration may be one of the most important soil properties, helping to increase soil water storage, to mitigate soil erosion, and to decrease the risk of flash floods and droughts.

HOLSTEN et al. (2009) studied past trends and possible future effects of climate change on soil moisture dynamics in Brandenburg. The authors found in the modelled climate scenarios that a $4-15 \%$ decrease in the average available soil water could be expected by the middle of the 21 st century.

HERNÁDI et al. (2009) evaluated the soil water regime and soil water balance elements of various textural classes of Hungarian Chernozem soil using the SoilWater-Atmosphere-Plant (SWAP) simulation model (VAN DAM, 2000). The authors used daily downscaled meteorological data from the A2 (temperature increase with decreasing precipitation) and $\mathrm{B} 2$ (scenario involving more frequent extreme climate conditions) climate scenarios of the Hadley Centre (2070-2100) and data for the reference period 1961-1990. Their results indicated that, compared to the present situation, by the end of the century a much lower amount of water would be stored in Chernozem soils in years representing average weather conditions (years with the most frequent occurrence). In such years, the shortage of water would be as severe as in extremely dry years in the present climate. The authors called attention to the need to develop various soil and water management strategies that could reduce the drought sensitivity of agricultural soils in the Carpathian Basin.

The predicted changes in the spatial and temporal distribution of annual precipitation would result in an increase in the duration and severity of soil water stress in soils. Both excessive amounts of rainfall (e.g. waterlogging) and lack of precipitation (drought) could result in unfavourable soil conditions for both natural and agroecosystems (FARKAS et al. 2014).

CALANCA (2007) analysed the probability of drought occurrence and severity in the Alps, based on a climate scenario that indicated the increasing likelihood of droughts in the Alpine region. The applied climate scenario by CALANCA (2007) projected a decrease of about $20 \%$ in the frequency of wet days during the growing season of summer crops. Under these conditions the frequency of droughts was shown to increase from about $15 \%$ to more than $50 \%$.

\section{Soil organic carbon}

Recent studies have suggested that the impact of climate change on SOC stocks due to balanced interacting mechanisms could not result in such dramatic losses of carbon from the soils as earlier predictions highlighted by GOTTSCHALK et al. (2015). The relationship of soil water retention to organic carbon content is also affected by the ratio of textural components, as RAWLS et al. (2003) found that the water retention of soils with coarse texture is substantially more sensitive to the amount of organic carbon than that of fine-textured soils. The effect of changes in organic carbon content on soil water retention depends on the ratio of textural components and the amount of organic carbon present in the soil.

In a litter bag experiment WALTER et al. (2013) studied the effect of climate change on decomposition in a temperate grassland and found that decomposition 
was reduced when litter bags were exposed to drought for six weeks within an 11month period. Their results showed that frequent cutting on grassland greatly stimulated decomposition.

Soil moisture stress may significantly reduce healthy soil functioning, consequently affecting plant productivity (MILLS et al., 2014). BUYTAERT et al. (2011) noted that drier and warmer soil conditions may cause an increase in organic carbon turnover, while changes in precipitation can impact the water supply. The authors also highlighted the negative effects of precipitation changes on hydrophysical soil properties in the long term due to the accelerated organic matter decomposition under wet conditions (BUYTAERT et al., 2011).

\subsection{Soil chemical properties and climate change}

Some of the most important soil chemical properties are the $\mathrm{pH}$, soluble salt content (indicated by electric conductivity), nutrient and carbonate contents and their distribution in soil profile, cation exchange capacity (CEC) and the base saturation (BS) value. While it is crucial to consider soil carbon cycling to obtain a better understanding of soil chemical responses to climate change, the topic is too large for the present paper; therefore, the focus is limited to some of the direct impacts on soil chemical properties.

Soil $\mathrm{pH}$ is determined by the parent material, the rate of weathering, the vegetation and the climate, so it is not expected to change rapidly due to the direct effects of climate change. Increasing precipitation, however, can intensify leaching and lead to soil acidification. Soil acidification affects soil chemistry, since low $\mathrm{pH}$ values promote the mobilization of potentially toxic elements (heavy metals), and can result in the depletion of basic cations through leaching (BRINKMAN, 1990) in soil that is well drained, structurally stable, and receives high amounts of intense rainfall, as in many upland areas of Europe. In a wetter climate, soil acidification could increase if buffering pools become depleted.

CROCKER \& MAJOR (1995) investigated glaciated soil surfaces and their changes due to vegetation and surface age over 16 to 28 years. The projected 50year changes showed that soil $\mathrm{pH}$ could drop significantly if vegetation starts to grow, while on a bare soil surface the $\mathrm{pH}$ change may remain minimal for decades (CROCKER \& MAJOR, 1995). For example, when the authors studied alder (Alnus) growth parallel with changes in soil $\mathrm{pH}$, they observed a $\mathrm{pH}$ of 7.9 on bare soil, which dropped by increments of 0.7, 0.8 and 1.4 after 9, 12 and 18 years of Alnus growth, respectively (CROCKER \& MAJOR, 1995). The soil calcium carbonate content, on the other hand, decreased rapidly during the first 10 years under Alnus vegetation.

On the other hand, increasing temperature coupled with less precipitation (scenario 3) may lead to capillary water movement and the evaporation of the groundwater resulting in salt accumulation (i.e. salinization) in the soil (VÁRALlYAY, 2007).

CEC refers to the total amount of cations exchanged on soil colloid surfaces such as clay mineral and organic matter surfaces. The proportion of CEC that forms basic cations $\left(\mathrm{Ca}^{2+}, \mathrm{Mg}^{2+}, \mathrm{K}^{+}\right.$, and $\left.\mathrm{Na}^{+}\right)$is termed as the percentage base cation 
saturation (BS\%), where the BS\% of soils generally increases with an increase in soil $\mathrm{pH}$. Very acidic soils might have high concentrations of $\mathrm{H}^{+}$and $\mathrm{Al}^{3+}$, while in neutral and moderately alkaline soils mainly $\mathrm{Ca}^{2+}$ and $\mathrm{Mg}^{2+}$ dominate (ROBERTSON et al., 1999). The quality and ratio of adsorbed cations have important roles in the development of soil aggregate structure, and consequently in the management of soil water (AMEZKETA 1999). $\mathrm{Ca}^{2+}$, as a special "glue", is able to maintain and protect the soil aggregate structure, while in the case of salt-affected soils (especially in Solonetzes), the high amount of $\mathrm{Na}^{+}$in the adsorbed cations (high sodium adsorption ratio, SAR value) causes poor, diffluent aggregate structure and therefore poor water management in the soil. DAVID and DIMITRIOS (2001) investigated saline structured soils with different $\mathrm{Na}^{+}$and $\mathrm{Ca}^{2+}$ solutions and SAR values. The authors found that $\mathrm{Na}^{+}$and $\mathrm{Ca}^{2+}$ had similar initial rates of release from the soil, but later measurements (20-30 minutes) showed $\mathrm{Na}^{+}$diffusion in low salinity soils. The tensile strength of aggregates represents the maximum stress which can be applied to a soil without causing any disruption (HILLEL, 1980). RAHIMI et al. (2000) studied the effect of varying electrical conductivity (EC), SAR and soil organic matter on tensile strength. The authors observed greater tensile strength in treatments with higher EC values and organic matter, while an increase in SAR decreased tensile strength (RAHIMI et al., 2000). Four climatic conditions (along a climatic transect) were represented in a study investigating soil aggregation responses to different rainfall amounts (SARAH, 2005). The study showed a nonlinear response along the climatic transect of change in soil structure characteristics, with improving soil structure from the arid to the Mediterranean zone, which was mainly influenced by soil organic matter content, but also by EC, SAR and the potassium adsorption ratio (SARAH, 2005).

CHADWICK et al. (2003) studied soil surface exchange properties such as base cation saturation, $\mathrm{pH}$ and effective cation exchange capacity (ECEC) as a function of the leaching index (LI), which was defined as 1 for areas with mean average precipitation (MAP) higher than $1400 \mathrm{~mm}$. They found that soils with LI below 1 had high base cation saturation and high ECEC, with close to neutral $\mathrm{pH}$. When MAP was above $1400 \mathrm{~mm}$, a decrease in soil $\mathrm{pH}$ and ECEC could be observed due to loss of buffering capacity (CHADWICK et al., 2003). Loss of buffering capacity can also result in the transport of biological acidity deeper into the vadose zone. The authors also found that the nonlinear decline in ECEC may be irreversible under natural conditions; base cation-depleted soils will remain depleted even if the climate shifts to drier conditions (CHADWICK et al., 2003). In contrast, a shift to wetter climate conditions may drastically modify the surface chemical properties existing in drier soils, as weathering depletes primary minerals, which may be further lost due to leaching, and causing a substantial alteration in surface chemistry. RUIZ-SINOGA \& ROMERO DIAZ (2010) studied eight soil profiles along a pluviometric sequence in Spain. The obtained data from wet to dry sites showed an almost continuous decline in organic matter and clay content and a decrease in CEC (RUIZ-SINOGA \& ROMERO DIAZ, 2010). LAVEE et al. (1998) reported that relatively small changes in climate may push many Mediterranean areas into a more arid and eroded landscape, featuring a decrease in organic matter content, aggregate size and 
stability, and an increase in SAR and the runoff coefficient. A lower organic matter content in the soil means smaller available surfaces for adsorption and leads to a decrease in CEC (LAVEE et al., 1998)

Soils forming in recently rejuvenated landscapes contain more primary minerals and could experience a loss of buffering capacity in the case of higher rainfall (VITOUSEK et al., 2003; CHADWICK et al., 2003; White \& BRANTLEY, 1995). The transfer of biological acidity through terrestrial subsurfaces depends on the present and past climate, along with the age and erosional stability of the landscape (CHADWICK et al., 2003).

Another important aspect of soil fertility and soil quality, the cycle of nutrients, especially nitrogen, in the soil, is closely coupled to the water and carbon cycles. Soil chemical properties influence soil physical and ecological behaviour (CHADWICK et al., 2003) and interact with physical and biological soil processes Together they determine the quality of the soil, including its biological activity, nutrient regime and soil fertility. Therefore, factors affecting the water regime and carbon cycle will affect nutrient availability as well.

An increase in the annual amount of rainfall (scenarios 2 and 4) accelerates carbonate loss in the profile, and percolation is one of the most important factors in carbonate leaching, was investigated by EGLI \& FITZE (2001) in Switzerland. The authors found that its rate amounted to approximately 1.7-3.0 mol m mear $^{-1}$ when normalized to $1000 \mathrm{~mm}$ soil water fluxes. In soils on coarse parent material slightly lower carbonate dissolution rates were detected in the order of approximately 1.7$2.2 \mathrm{~mol} \mathrm{~m}^{-2}$ year $^{-1}$, while other sites with smaller grain sizes had slightly higher dissolution rates of 2.2-3.0 mol m${ }^{-2}$ year $^{-1}$ (EGLI \& FITZE, 2001).

Increasing annual amounts of precipitation may intensify the downward filtration and leaching in soils, consequently sub-serving acidification. The acidification process may increase the mobilization of toxic elements (e.g. heavy metals) and result in unfavourable conditions for plants and other living organisms. KOPITTKE et al. (2012) investigated soil acidification processes based on a 13-year manipulative climate experiment involving repeated drought. Drought events were simulated in summer during the vegetation period, while non-drought (control) treatments were also applied. The authors found that the $\mathrm{pH}$ of the soil solution decreased in both treatments, but the $\mathrm{pH}$ values in the control plots were more acidic than in the drought treatment. The results indicated that drought counteracted the acidification process.

Climate change might result in a rise in the eustatic sea level, consequently leading to more extensive flooded areas and salt accumulation from sea water vapour on shorelines. For example, in the case of scenario 3 (Fig. 1) the increasing temperature and decreasing annual precipitation lead to less intensive leaching in the soils. This could intensify salinization and/or carbonate accumulation processes, and may result in salic-, gypsic-, calcic horizons or hard pan development. A possible increase in the amount of irrigation water and inadequate irrigation practices could lead to extensive secondary salinization (RENGASAMY, 2006).

In recent salt-affected regions, where the source of salt is the shallow groundwater and a decrease in its level is predicted, the upward capillary transport 
will be reduced, so less soluble salts will be transported towards the surface (VÁRALLYAY, 2007).

Vegetation growth may be adversely affected by changes in both temperature and precipitation intensity. Alterations in soil moisture content affect plant productivity, water stress and soil biogeochemistry (PORPORATO et al., 2004). Especially in agricultural settings, changes in climatic factors may have a great influence on crop growth. KROES \& SUPIT (2011) analysed the effect of drought, water excess and salinity on grass production in The Netherlands. The authors observed that drought stress may be more severe than the stress caused by water excess, which in its turn is stronger than salinity stress. However, the rate of water loss is another important factor in water stress, as slower water loss gives the plants time to acclimatise (BRAY, 1997), therefore lessening the long-term effects of water deficit. CHAVES et al. (2002) investigated various plant species and the mechanisms they used to cope with water stress. In the case of Lupinus albus, the authors found that water-stressed plants reduced their leaf area to half compared to well-watered plants, while increases in root length density and stem biomass were observed under water-stress conditions (CHAVES et al., 2002).

\section{Climate change and soil degradation}

Soil degradation induced by climate change here refers to a change in soil quality mainly due to water erosion and wind erosion, or degradation caused by a change in vegetation cover. In areas where the soil-water budget was previously balanced, intensifying evaporation may make this budget evaporation-dominant, leading to more intensive upward water movement and a potential risk of salinization, especially in regions where saline groundwater is near the surface. Soil erosion rates may be expected to change in response to climate change for a variety of reasons. Soil degradation is a very important factor and can significantly affect hydro-physical soil properties. Soil erosion and degradation is a very wide-ranging topic, so the present paper will concentrate mainly on soil degradation processes as an accelerated climate change impact on soil hydro-physical and biogeochemical processes. The soil erosion time-wise is a relatively short-term process. The influence of climate change on erosion rates is primarily due to the erosive power of rainfall, but changes in plant biomass may also be a powerful factor.

The interaction between biomass and climate change, as influencing elements of runoffs and soil erosion, can be a very complex mechanism (PRUSKI \& NEARING, 2002). The rate, type and extent of soil erosion depend on the combined influences of climate, e.g. the quantity and intensity of rainfall, relief, vegetation (type, continuity, density) and soil erodibility characteristics (FAVIS-MORTLOCK \& BOARDMAN, 1995; VÁRALlYAY, 2007; VERHEIJEN et al., 2009; LAL, 2010; Mullan et al., 2012; SHIONO et al., 2013). Climate change may cause changes in plant biomass and land use by shifting natural vegetation cover or agricultural practices. Changes in the extent of vegetation cover due to changing water supplies can modify or counterbalance the direct impact of rainfall. Less precipitation itself may reduce water erosion, while the cohesion between soil particles may decrease 
due to moisture loss (VERMEIRE et al., 2005), resulting in accelerated wind erosion. Wind erosion may reduce soil nutrient reserves by removing the finest soil particles, which contain the largest amounts of plant nutrients (GOMES et al., 2003), therefore affecting vegetation growth. YAN et al. (2005) investigated changes in the SOC and net primary production (NPP) of soils in China in terms of wind erosion intensity and found significant decreases in both SOC and NPP with increasing wind intensity. BÄRRING et al. (2003) outlined scenarios for future changes in the wind climate in Scania (Sweden). Although the total impact of the climatic forcing of wind erosion was uncertain, the model indicated that in a warmer climate the mean wind speed locally may increase up to $20 \%$ along the northern Baltic coast of Sweden and north of Scania as well, as a result of changing sea-ice conditions that strengthen wind erosion (BÄRRING et al. 2003).

RUIZ-SINOGA \& ROMERO DIAZ (2010) investigated soil degradation processes in Southern Spain along a pluviometric gradient of mean annual rainfall from 270 $\mathrm{mm}$ (arid conditions) to $1100 \mathrm{~mm}$ (wet conditions). A clear threshold was found at about $500 \mathrm{~mm}$ per year, separating arid eco-geomorphological systems (controlled by abiotic factors such as soluble salts and mechanical crust formation) from humid eco-geomorphological systems (controlled by biotic processes such as plant growth, microbial activity, organic matter production and decomposition) (RUIZ-SINOGA \& ROMERO DIAZ, 2010; LAVEE et al., 1998). After monitoring soil structural variables for 3 years under arid and Mediterranean climate conditions, SARAH (2005) found a high correlation between the mean annual rainfall and annual rainfall variability and a number of aggregation variables. Aggregate stability increased, while the microparticle percentage decreased with decreasing rainfall.

One of the most important direct impacts of precipitation change induced soil erosion is the aggregate destructing role of raindrops, surface runoff, and filtrating water. The rate of structure damage depends on the intensity of the destroying factor and the stability of soil aggregates against these actions (JAKAB et al., 2016). The consequences of vegetation changes on soil structure (desertification, waterlogging, salinity-alkalinity changes) can be either favourable or unfavourable (FARKAS et al., 2014). The impact of over-grazing, irrational land use, misguided agricultural utilization (cropping pattern, crop rotation) and inappropriate technologies (heavy machinery, over-tillage, over-irrigation) is unfavourable, often irreversible and almost impossible to correct (LI et al., 2010). On the other hand, rational land use, appropriate technologies and amelioration practices may help to maintain or restore good soil structure (VÁRALLYAY, 2007).

Modelling the impact of climate change on soil erosion is subject to many uncertainties and restrictions in terms of data availability and the knowledge of underlying processes. Most importantly, there are no linear relationships between mean annual precipitation, surface runoff and the rate of denudation/erosion. SHIONO et al. (2013) investigated the rainfall erosivity factor based on six GCM models with three emission scenarios (A1B, A2 and B1) and found that the projected climate change would increase the soil erosion of farmlands in Japan by over $20 \%$ by 2100 . MulLAN et al. (2012) modelled soil erosion using climate change projections from the United Kingdom (HadCM3), Canada (CGCM2) and 
Australia (CSIROMk2) and concluded that both increases and decreases in erosion rates could occur depending on the type of scenario used. Model simulations based on downscaled climate change projections suggested a decrease in erosion, while large changes in daily annual precipitation frequency resulted in a great increase in erosion (MULLAN et al., 2012).

\section{Climate change scenarios in the Central European region}

Widely applied methods for forecasting the possible effects of climate change on soils are i) model based simulations using downscaled General Circulation Models (GCMs) that calculate with spectra of possible changes; and ii) the investigation of paleo-climatic data records and their detectable interactions with paleosols (KUTíLEK, 2011). The climatic parameters used for describing an environment are quantities which represent averages for certain time intervals, often 30 years.

Global climate models forecast heterogeneous spatial and temporal patterns of temperature change, especially in the northern continental regions of North America and Eurasia, although CUBASH et al. (2013) highlighted that global climate model simulations are still uncertain. The pattern of changing temperature is projected to be accompanied by considerable changes in precipitation, in terms of both the quantity and form of precipitation, and its spatial and temporal distribution.

According to the GCMs the change in annual total precipitation will occur with high spatial variability and considerable regional redistribution. Later, however, these tendencies will be counterbalanced by the increasing evaporation from water surfaces, especially from oceans. The increasing evaporation will lead to greater air humidity and probably more precipitation, again with more uneven spatial and temporal distribution, and to the increasing frequency of heavy rainfall and extreme weather events (droughts, storms, floods, etc.). Therefore, the frequency of extreme weather events will probably increase in the future (MEEHL et al., 2000; IPCCAR5), its effect on soil properties should also be evaluated.

Climate model results based on the A1B non-mitigation scenario suggest $3.5^{\circ} \mathrm{C}$ warming on average for Europe for the period 2071-2100 compared to the reference period (1961-1990), with considerable spatial inhomogeneity and a temperature increase as high as $5^{\circ} \mathrm{C}$ average for summer in some parts of Europe (ClimateCost). This extreme value makes it clear how important it is to address the potential effect of these projected changes on the soil hydro-physical and chemical properties.

Projections for precipitation change are uncertain (CLIMATECOST; IPCC AR5), but there are common patterns regarding precipitation trends. Wetter winters are projected for the Western and Northern parts of Europe, while a decrease in precipitation in all seasons is projected for Southern Europe. In other parts of Europe, located between these two regions, moderate precipitation changes are projected and regional climate models even tend to give conflicting results (KRÜZSElYI et al., 2011; ClimateCost). The Carpathian Basin is one of the regions located in the intermediate zone between probable increase and decrease in 
annual precipitation amounts. Hence, the Carpathian Basin is one of the most questionable areas in Europe with respect to its future climate. The area is currently subject to periodic droughts with harmful effects on agriculture (e.g. soil moisture deficit, porosity decrease) so it is crucial to develop suitable adaptation strategies for the possible outcomes of climate change. The Carpathian region lies in the transition area between Northern and Southern Europe, where climate models in the PRUDENCE project indicated an increase in annual precipitation totals in the northern parts of the continent and a decrease in southern parts (CHRISTENSEN \& CHRISTENSEN, 2007).The exact location of this transition, where no precipitation change is expected, is very uncertain and there could be seasonal variations. The transition zone is likely to be located more northerly in summer and more southerly in winter (GIORGI \& LIONELLO, 2008; BARTHOLY et al., 2011), this causing a seasonal pattern in the expected trend of precipitation amount in the Carpathian Basin. A regional climate model (RCM) mini-ensemble experiment, accomplished using four distinct RCMs for the periods 2021-2050 and 2071-2100, proposed increasing precipitation amounts in winter and decreasing totals in spring and summer for the Carpathian Basin by the end of the $21^{\text {st }}$ century, although the annual totals are expected to decrease to some extent. However, due to the uncertainty of this 4-member ensemble, it is also possible that there will be no difference or even a slight increase in annual precipitation totals (KRÜZSELYI et al. 2011), as corroborated by past trends, based on the interpolated, homogenized surface database of the Hungarian Meteorological Service. Observed trends showed a decrease in annual precipitation amount with unequal spatial distribution in Hungary since 1901, with the biggest decreases during the spring (LAKATOS \& BIHARI, 2011).

A change in the temporal distribution of precipitation has also been discussed. Observed global trends show an increase in the contribution of very wet days (95th percentile) to the total annual precipitation (IPCC, 2007). For the future, climate models projected an increase in heavy summer precipitation in Northern Europe, and a decrease in the south (BENISTON et al., 2007), with increasing winter precipitation in central European regions (BENISTON et al., 2007; BARTHOLY et al., 2007). Trends in precipitation indices, characterizing the temporal distribution of precipitation in Hungary, have also been investigated in the frame of the miniensemble project (BARTHOLY et al., 2011). The results indicated a decrease in the frequency of rainy days with non-extreme rainfall $(\mathrm{P}<1 \mathrm{~mm}, \mathrm{P}<5 \mathrm{~mm})$ for both future periods. The frequency of days with heavier precipitation $(\mathrm{P}>10 \mathrm{~mm} ; \mathrm{P}>20$ $\mathrm{mm})$ and precipitation intensity will probably increase. Precipitation extremes on the territory of Hungary were also investigated on the basis of observations (LAKATOS \& BIHARI, 2011), which show that Hungary has already been experiencing similar trends. The number of rainy days (with precipitation $>1 \mathrm{~mm}$ ) has decreased. Seasonal shifts in precipitation and the projected changes in its intensity raise concerns for the soil water regime under different vegetation conditions in the region, so investigations on the expected impact and the planning of adaptation strategies are of high priority. 


\section{Conclusions}

The state of any ecosystem is largely determined by the soil conditions, which are dependent on the climate in general and on precipitation in particular. Investigations on the soil water regime can provide indicative results for many aspects of ecosystem functioning. Hence, we need to focus on exploring the expected impacts of climate change on the soil water regime, and on investigating the potential of land use changes to mitigate the negative effects of climate change. In terms of the expected long-term changes in annual precipitation totals the Carpathian Basin is a transitional area. However, both regional climate models and the comparative analysis of periodical climate data forecast significant warming in this region during the $21^{\text {st }}$ century, accompanied by severe drought events.

\section{Acknowledgements}

This study was supported by the National Research Fund (OTKA/NKFI) projects OTKA K-101065, PD-116084 and PD-116157. This paper was supported by the János Bolyai Research Scholarship of the Hungarian Academy of Sciences. The research was supported by the Széchenyi 2020 program, by the European Regional Development Fund 'Investing in your future' and by the Hungarian Government (GINOP-2.3.2-15-2016-00028).

\section{References}

AMEZKETA, E. 1999. Soil aggregate stability: A review. Journal of Sustainable Agriculture. 14. (2-3) 83-151.

ANDERSON, D.W. 1988. The effect of parent material and soil development on nutrient cycling in temperate ecosystems. Biogeochemistry. 5. 71-97.

Bard, D., Burch, B., Robinette, C., Weibley, E., Wentz, C. \& VAsilas L. 2017. Soil Study Guide. Maryland Envirothon. http://mdenvirothon.org/wp-content/uploads/2017/12/soil-studyguide revised 2017.pdf

Bartholy J., Horányi A., KrüzSelyi I., PieczKa I., Pongrácz R., SZabó P., SZÉPSZÓ G. \& TORMA C. 2011 A várható éghajlatváltozás dinamikus modelleredmények alapján. In: BARTHOLY J., BOzÓ L. \& HASZPRA L. (ed.): Klímaváltozás - 2011 MTA-ELTE Meteorológia Tanszék - Budapest - 2011 -281 p. ISBN: 978-963-284-232-5

Bartholy, J., Pongrácz, R. \& Gelybó, G. 2007. Regional climate change expected in Hungary for 2071-2100. Applied Ecology and Environmental Research. 5. 1-17.

BÄRRING, L., JÖNSSON, P., MATTSSON, J.O. \& ÅHMAN, R. 2003. Wind erosion on arable land in Scania, Sweden and the relation to the wind climate-a review. Catena. 52. 173-190. 
Beniston, M., Stephenson, D.B., Christensen, O.B., Ferro, C.A.T., Frei, C., Goyette, S., Halsnaes, K., Holt, T., Jylhä, K., Koffi, B., PAlutikof, J., SCHÖLl, R., SEMMLER, T. \& WOTH, K. 2007. Future extreme events in European climate: an exploration of regional climate model projections. Climatic Change. 81. 71-95.

BIRKÁS, M., DEXTER, A. \& SZEMŐK, A. 2009. Tillage-induced soil compaction, as a climate threat increasing stressor. Cereal Res Commun. 37. 379-382.

BIRKELAND, P.W. 1999. Soils and Geomorphology. 3rd ed. Oxford University Press, New York

BoCKHEIM, J.G. 1980. Solution and use of chronofunctions in studying soil development. Geoderma. 24. 71-85.

Bockheim, J.G., Gennadiyev, A.N., HarteminK, A.E. \& BreviK E.C. 2014. Soil forming factors and soil taxonomy. Geoderma. 226-227. 231-237.

BORMANN, H. 2012. Assessing the soil texture-specific sensitivity of simulated soil moisture to projected climate change by SVAT modelling. Geoderma. 185186. 73-83.

BRAY, E.A. 1997. Plant response to water deficit. Trends in Plant Science. 2. 4854.

BRINKMAN, R. \& BRAMMER, H. 1990. The influence of a changing climate in soil properties. In: Trans. 14th ISSS Congress, Kyoto, 1990, 5. 283-287.

Buytaert, W., Cuesta-CAmacho, F. \& Tobon, C. 2011. Potential impacts of climate change on the environmental services of humid tropical alpine regions. Global Ecology and Biogeography. 20. 19-33.

CALANCA, P. 2007. Climate change and drought occurrence in the Alpine region: How severe are becoming the extremes? Global and Planetary Change. 57. $151-160$.

Chaves, M.M., Pereira, J.S., Maroco, J., Rodrigues, M.L., Ricardo, C.P.P., Osorio, M.L., Carvalho, I., Faria, T. \& Pinheiro, C. 2002. Plants cope with water stress in the field. Photosynthesis and growth. Annals of Botany. 89. 907-916.

Christensen, J.H. \& Christensen, O.B. 2007. A summary of the PRUDENCE model projections of changes in European climate by the end of this century. Climatic Change. 81. 7-30.

Crocker, L. \& MAJOR, J. 1955. Soil development in relation to vegetation and surface age at Glacier bay, Alaska. Journal of Ecology. 43. 427-448.

Cubasch, U., Wuebbles, D., Chen, D., Facchini, M.C., Frame, D., Mahowald, N. \& Winther, J.-G., 2013. Introduction. In: Climate Change 2013: The Physical Science Basis. Contribution of Working Group I to the Fifth Assessment Report of the Intergovernmental Panel on Climate Change In: Stocker, T.F., Qin, D., Plattner, G.-K., Tignor, M., Allen, S.K., Boschung, J., Nauels, A., XiA, Y., BeX, V. \& Midgley, P.M. (eds.). Cambridge University Press, Cambridge, United Kingdom and New York, NY, USA 
DOKUCHAEV, V.V. 1899. K ucheniiu o zonakh prirody: Gorizontal'nye i vertikal'nye pochvennye zony. St. Petersburg, 1899. Learnings about environmental zonality. Horizontal and vertical soil zones. (in Russian). http://www.geokniga.org/books/3459

FARKAS, C. 2009. Stochastic assessment of climate change effects on soil water regime in the Hungarian Bodrog Interfluve Region. In: HALASI-KUN, G. Ed. Scientific and Social-Institutional Aspects of Central Europe and USA. Pollution and Water Resources. Columbia University Seminar Proceedings; New York-Bratislava: Columbia University, 2008-2009; vol. XXXVIIIXXXIX. 348-366.

FArKas, C., Hernádi, H., MaKÓ, A., MÁTÉ, F. 2009. Mészlepedékes csernozjom talajok talajváltozatainak klímaérzékenysége. "Klíma-21" füzetek. 57. 15-30.

Farkas, C., Gelybó, G., BaKacsi, Z., Horel, A., Hagyó, A., Dobor, L., Kása, I. \& То́тH, Е. 2014. Impact of expected climate change on soil water regime under different vegetation conditions. Biologia. 69. 1510-1519.

FAVIS-MORTLOC, D. \& BOARDMAN, J. 1995. Nonlinear responses of soil erosion to climate change: a modelling study on the UK South Downs. Catena. 25. 1365 387.

GioRGi, F. \& LiONELlO, P. 2008. Climate change projections for the Mediterranean region. Global and Planetary Change. 63. 90-104.

Gomes, L., Arrue, J.L., Lopez, M.V., Sterk, G., Richard, D., Gracia, R., SABRE, M., GAUdichet, A. \& FrANGI, J.P. 2003. Wind erosion in a semiarid agricultural area of Spain: the WELSONS project. Catena. 52. 235-256.

Gottschalk, P., Smith, J.U., Wattenbach, M., Bellarby, J., Stehfest, E., ARnell, N., Osborn, T. J., Jones, C. \& SMITH, P. 2012. How will organic carbon stocks in mineral soils evolve under future climate? Global projections using RothC for a range of climate change scenarios, Biogeosciences. 9. 31513171.

Hernádi, H., FARKAS, C., MAKÓ, A. \& MÁté, F. 2009. Climate sensitivity of soil water regime of different Hungarian Chernozem soil subtypes. Biologia. 64. 624-628,

HILlEL, D. 1973. Soil and Physical principles and processes ( $3^{\text {rd }}$ ed). Academic Press, Inc. 248 p.

Holsten, A., Vetter, T., Vohland, K., \& Krysanova, V. 2009. Impact of climate change on soil moisture dynamics in Brandenburg with a focus on nature conservation areas. Ecological Modelling. 220. 2076-2087.

Horel, Á., Tóth, E., Gelybó, Gy., KÁSA, I., BAKACSI, Zs. \& FARKAS, Cs. 2015. Effect of land use and management on soil hydraulic properties. Open Geoscience. 1. 742-754.

Hotchiss, S., Vitousek, P.M., Chadwick, O.A. \& Price, J., 2000. Climate cycles, geomorphological change, and the interpretation of soil and ecosystem development. Ecosystems. 3. 522-533.

IPCC Climate Change, 2007. Working Group II: Impacts, Adaptation and Vulnerability, 13.2.1.2.3. Biologically mediated soil properties. http://www.ipcc.ch/ipccreports/tar/wg2/index.php?idp=498 
IstanbulluOGlu, E. \& BRAS, R.L. 2006. On the dynamics of soil moisture, vegetation, and erosion: implications of climate variability and change. Water Resources Research. 42. W06418.

Jakab, G., Szabó, J., Szalai, Z., Mészáros, E., Madarász, B., Centeri, Cs., SZABÓ, B., NÉMETH, T. \& SiPOS, P. 2016. Changes in organic carbon concentration and organic matter compound of erosion-delivered soil aggregates. Environmental Earth Sciences. 75. 144.

JenNY, H. 1941. Factors of Soil Formation. A System of Quantitative Pedology. McGraw Hill Book Company, New York, NY, USA. 281 p. ISBN: 0486681289

KopittKe, G.R., TiETEMA, A. \& Verstraten, J.M. 2012. Soil acidification occurs under ambient conditions but is retarded by repeated drought: Results of a field-scale climate manipulation experiment. Science of the Total Environment. 439. 332-342.

KrüZselyi, I., B ARTholy, J., Horányi, A., PieczKa, I., PONGRÁcz, R., SZABÓ, P., SZÉPSZÓ, G. \& TORMA, Cs. 2011. The future climate characteristics of the Carpathian Basin based on a regional climate model mini-ensemble. Advances in Science and Research. 6. 69-73.

KuTíLEK M. 2011. Soils and climate change. Soil and Tillage Research. 117. 1-7.

LAKATOS, M. \& BIHARI, Z., 2011. A közelmúlt megfigyelt hőmérsékleti- és csapadéktendenciái. In: BARTHOLY J., BOZÓ L., HASZPRA L. (eds.): Klímaváltozás - 2011 MTA-ELTE Meteorológia Tanszék - Budapest - 2011 -281p. ISBN: 978-963-284-232-5

LAL, R. 2010. Beyond Copenhagen: mitigating climate change and achieving food security through soil carbon sequestration. Food Security. 2. 169-177.

LÁNG, I., CSETE, L. \& JOLÁNKAI, M. 2007. A globális klímaváltozás: hazai hatások és válaszok. A VAHAVA jelentés. Szaktudás Kiadó Ház, Budapest. (in Hungarian)

LaVee, H., Imeso, A.C. \& SARAH, P. 1998. The impact of climate change on geomorphology and desertification along a Mediterranean-arid transect. Land Degradation \& Development. 9. 407-422.

LI, S., LOBB, D.A. \& MCCONKEY, B.G. 2010. The impacts of land use on the risk of soil erosion on agricultural land in Canada. In: World Congress of Soil Science, Soil Solutions for a Changing World Brisbane, Australia.

MACK, G.H. 1991. Paleosols as an indicator of climatic change at the early-late cretaceous boundary, Southwestern New Mexico. Journal of Sedimentary Petrology. 62. 483-494.

Meehl, G.A., Zwiers, F., Evans, J., Knutson, T. Mearns, L. \& Whetton, P. 2000. Trends in extreme weather and climate events: Issues related to modeling extremes in projections of future climate change. Bulletin of the American Meteorological Society. 81. 427-436.

Mills, R.T.E., Gavazov, K.S., Spiegelberger, T., Johnson, D. \& Buttler, A. 2014. Diminished soil functions occur under simulated climate change in a sup-alpine pasture, but heterotrophic temperature sensitivity indicates microbial resilience. Science of the Total Environment. 473-474. 465-472. 
Molnar, P. \& England, P.1990. Late Cenozoic uplift of montain ranges and global climate change: chicken or egg? Nature. 346. 29-34.

MULLAN, D., FAVIS-MORTLOCK, D. \& FEALY, R. 2012. Addressing key limitations associated with modelling soil erosion under the impacts of future climate change. Agricultural and Forest Meteorology. 156. 18- 30.

Chadwick, O.A., Gavenda, R.T., Kelly, E.F., Ziegler, K., Olson, C.G., CRAWFORD ElLIOTT, W. \& HENDRICKS D.M. 2003. The impact of climate on the biogeochemical functioning of volcanic soils. Chemical Geology. 202. $195-223$.

Pivchenko, D. 2010. Climate as a factor of soil formation. BSc thesis, Moscow Agricultural Academy named after Timiryazev, Moscow. (in Russian)

PorPorato, A., DALY, E. \& RodrigueZ-ItURBe, I. 2004. Soil water balance and ecosystem response to climate change. The American Naturalist. 164. 625-32.

Post, W., EMANUEL, W., ZINKE, P. \& STANGENBERGER, A. 1982. Soil carbon pools and world life zones. Nature. 298. 156-159.

PRUSKI, F.F. \& NEARING, M.A. 2002. Runoff and soil loss changes expected for changes in precipitation patterns under global climate change. J. Soil Water Conserv. 57. 7-16.

RAHIMI, H., PAZIRA, E. \& TAJIK, F. 2000. Effect of soil organic matter, electrical conductivity and sodium adsorption ratio on tensile strength of aggregates. Soil \& Tillage Research. 54. 145-153.

RAWLS, W. J., PACHEPSKY, Y.A., RITCHIE, J. C., SOBECKI, T. M., \& BLOODWORTH, H. 2003. Effect of soil organic carbon on soil water retention. Geoderma. 116. 61-76.

RENGASAMY, P. 2006. World salinization with emphasis on Australia. Journal of Experimental Botany. 57. 1017-1023.

Reubens, B., Poesen, J., DAnjon, F., Geudens, G. \& Muys, B. 2007. The role of fine and coarse roots in shallow slope stability and soil erosion control with a focus on root system architecture: a review. Trees. 21. 385-402.

REY, A. 2015. Mind the gap: non-biological processes contributing to soil $\mathrm{CO}_{2}$ efflux. Global Change Biology. 21. 1752-1761.

RoBERTSON, G.P., SOlLINS, P., ELLIS, B.G. \& LAJTHA, K. 1999. Exchangable ions, $\mathrm{pH}$, and cation exchange capacity. In: Standard Soil Methods for Long-Term Ecological Research, Oxford University Press, New York. 106-111.

Rosenzweig, C. \& HiLlel, D. 1995. Potential impacts of climate change on agriculture and food supply. Consequences. 1. 24-31.

Rounsevell, M., Evans, S.P. \& Bullock, P. 1999. Climate change and agricultural soils: impacts and adaptation. Climatic Change. 43. 683-709.

SARAH, P. 2005. Soil aggregation response to long- and short-term differences in rainfall amount under arid and Mediterranean climate conditions. Geomorphology. 70. 1-11.

Scharpenseel, H.W., Schomaker, M. \& Ayoub, A. (eds.) 1990. Soils on a Warmer Earth. Elsevier, Amsterdam, 274p.

Singh, B.P., CowIE, A.L. \& ChAN, K.Y. (eds.) 2011. Soil Health and Climate Change, Soil Biology, Springer-Verlag Berlin Heidelberg, 1-414. 
Shiono, T., Ogawa, S., Miyamoto, T. \& Kameyama, K. 2013. Expected impacts of climate change on rainfall erosivity of farmlands in Japan. Ecological Engineering, 61. 378-689.

SZÁSZ, G., CSELÖTEI, L., \& KovÁCS, G. J. 1994. Az időjárás és a növénytermesztés. In: Az agrárgazdaság jövöképe. (eds.: LÁNG, I., CSETE, L., DOHY, J., HARNOS, Z., KoCSIS, K. \& VÁrAllyaY, G.). 50-87. „AGRO-21” Füzetek. 1 „AGRO21" Kutatási Programiroda.

ŠUrda, P., Lichner, L., Nagy, V., Kollar, J., Iovino, M. \& Horel, A. 2015. Effects of vegetation at different succession stages on soil properties and water flow in sandy soil. Biologia. 70. 1474-1479.

Targulian, V.O. \& KrasilniKov, P.V. 2007. Soil system and pedogenic processes: Self-organization, time scales, and environmental significance. Catena. 71. 373-381.

Tóth, E., Gelybó, G., Dencső, M., KÁsa, I., BirKÁs, M. \& Horel, Á. 2018. Chapter 19 - Soil $\mathrm{CO}_{2}$ emissions in a long-term tillage treatment experiment A2 - Muñoz, María Ángeles. In: Soil Management and Climate Change. (ed. R. ZORNOZA), Academic Press, 293-307.

VAN DAM, J.C. 2000. Field-scale water flow and solute transport. Ph.D. thesis, Wageningen University, The Netherlands, $167 \mathrm{p}$.

VÁRALLYAY, G., 2005. Magyarország talajainak vízraktározó képessége. Agrokémia és Talajtan. 54. 1-8.

VÁRALlyay, G. 2007. Potential Impacts of Climate Change on Agro-ecosystems. Agriculturae Conspectus Scientificus. 72. 1-8.

VÁRALlYAY, G. 2008. Talaj-víz kölcsönhatások a klímaváltozás tükrében. Talajvédelem különszám. (in Hungarian) 17-30.

VÁRALLYAY, G. 2010. The impact of climate change on soils and on their water management. Agronomy Research. 8. (Special Issue II). 385-396.

VERHEIJEN, F.G., JONES, R.J., RICKSON, R.J. \& SMITH, C.J. 2009. Tolerable versus actual soil erosion rates in Europe. Earth-Science Reviews. 94. 23-38.

Vermeire, L.T., WeSter, D.B., Mitchell, R.B. \& FuhlendorF, S.D. 2005. Fire and grazing effects on wind erosion, soil water content, and soil temperature. Journal of Environmental Quality. 34. 1559-1565.

Vitousek, P., Chadwick, O., Matson, P., Allison, S., Derry, L., Kettley, L., Luers, A., MeCKING, E., Monastra, V., \& Porder, S. 2003. Erosion and the rejuvenation of weathering-derived nutrient supply in an old tropical landscape. Ecosystems. 6. 762-772.

Walter, J., Hein, R., Beierkuhnlein, C., HAMmerl, V., Jentsch, A., SchÄDler, M., SChuERINGS, J. \& KREYLING, J. 2013. Combined effects of multifactor climate change and land-use on decomposition in temperate grassland. Soil Biology \& Biochemistry. 60. 10-18.

White, A.F., \& BRANTLEY, S.L. 1995. Chemical weathering rates of silicate minerals: an overview. In: Chemical Weathering Rates of Silicate Minerals. White, A.F., Brantley, S.L. (eds.). Mineralogical Society of America, Chantilly, 1-22. 
YAALON, D.H. 1983. Climate, time and soil development. In: WILDING, L.P., SMECK, N.E. \& HALL, G.F. (eds.). Pedogenesis and Soil Taxonomy. I. Concepts and Interactions, Elsevier Science Publishers B.V., Amsterdam, The Netherlands. 233-251.

YAN H., WANG S., WANG C., Zhang G. \& PAtel N. 2005. Losses of soil organic carbon under wind erosion in China. Global Change Biology. 11. 828-840. 